\title{
The Dilemma of Violent Extremism and Conflict Escalation among Youths in Myanmar
}

\author{
Ephraim Bassey Emah \\ University of Notre Dame, IN 46556, United States
}

\begin{abstract}
Radicalisation and violent extremism remain a global concern that hinders peacebuilding in many ways. As youths become radicalised and participate in ethnic armies in Myanmar, their engagements are motivated by ethnonationalism agendas. Ethnonationalism encompasses the demand for political recognition, resource and territorial control, and liberation from structural injustices and repressive systems that marginalise ethnic minorities. These demands emerge from feelings of relative deprivation and frustration, which force ethnic armed organisations (EAOs) to seek recognition for their local constituencies. While several contemporary conversations conceptualise radicalisation and extremism in Myanmar from religious perspectives, they ignore the proliferation of political violence through ethnic ideologies as a form of extremism. Therefore, a clear understanding of extremism emerges when research questions why and how people radicalise, particularly when the phenomenon is viewed as an 'ecology' - a system with interconnected elements. Thus, the absence of systemic assessment of the structural factors that perpetuate vertical and horizontal forms of violence in Myanmar impedes a clear understanding of the complexity of the conflicts, and the motivations for youth indulgence in extremism. This research contributes to the understanding of politically-motivated grievances as a significant driver of violent extremism in Myanmar. Using research findings, it argues that violent extremism among youths in Myanmar is politically-motivated, emerging due to structural injustices perpetrated against ethnic minorities. These feelings result from relative deprivation, frustration and aggression, and the quest for significance, spurring a resolve to liberate one's ethnic group from repressive and hegemonic political systems that impede participatory opportunities to decision-making and leadership.
\end{abstract}

Keywords: Youth, Violent Extremism, Radicalisation, Ethnonationalism, Conflict.

\section{INTRODUCTION}

$\mathrm{C}$ onflict remains an intrinsic part of human interactions. However, with the emergence of ideologies, such as the Nazism, that radicalise individuals, conflict is taking a new turn globally. Historically, radicalisation and violent extremism existed in many societies, manifesting as either ideological or identity-based conflicts. They mutate the conventional understanding and manifestations of ideological or identity conflicts to ones that employ 'extremely radical rhetoric' in their perpetuation. While "violent extremism undermines collective efforts towards maintaining peace and security, fostering sustainable development, protecting human rights, promoting the rule of law and taking humanitarian action" (Ban, 2015), it should be subject to interpretation depending on the environments within which it manifests.

The concept of radicalisation and violent extremism is relatively contested across diverse fields. Rather than associating its manifestation with extremely radical religious teachings (Mandaville \& Nozell, 2017; Weinberg \& Pedahzur, 2004), as the case often is, systemic assessment of the contextual factors that cause people to radicalise should be assessed and understood. While many scholarly pieces of literature, policy strategies, and humanitarian programmes emphasise religion as the most salient method through which people radicalise, such understanding creates a linear and formulaic understanding of the problem. They neglect a full depth of other systemic factors that could constitute fundamental tools for radicalisation or the mobilisation of extreme violence in different environments. A critical understanding and assessment of violent extremism as an ecology (especially from a systemic lens) reveals the relationships among humans, institutions, social patterns, and the overall environment (Schirch, 2018). It also displays how a combination of these interactions fuels extreme violence. Proper assessment of the contextual factors that motivate extremism will inform solutions that transform conflicts and the radical ideologies that escalate them. Therefore, because multiple factors cause people to radicalise, theorising violent extremism, particularly under politically-motivated circumstances, requires an understanding of the intersection between different political, economic, social, ethnic, and religious factors and the theories of needs, feelings, and a quest for significance.

The protraction of violent conflicts in Myanmar (also known as Burma) is identified to be rooted in the "lack of legitimacy and capacity of successive military regimes to address contested visions of what constitutes the nation-state among the country's ethnic groups and political factions" (n/a, n/d). This competition for legitimacy affects relationships between ethnic minorities and the Central Government, including the provision of social services to areas where rebellion occurs. Even though many communities do not entirely support the sub-national rebellion, they rely extensively on the leadership of ethnic armed organisations (EAOs) in these contested areas to access education, healthcare delivery, and other essential services. While the rivalries continue, competing systems of governance have become sustained because of the attitude of the Central Government towards ethnic minorities. These 
factors inspire many youths in Myanmar's sub-national areas to engage in active resistance through their ethnic armies to establish political recognition for their ethnic groups.

Hence, this paper argues that radicalisation and violent extremism among youths in Myanmar is politically-motivated, emerging due to structural injustices perpetrated against ethnic minorities. These feelings result from relative deprivation, frustration and aggression, and the quest for significance, which spurs a resolve to liberate one's ethnic group from repressive and hegemonic socio-political systems that impede participatory opportunities to political decision-making and leadership. Understanding violent extremism in Myanmar as politically-motivated is necessary because it enables the assessment of the country's conflict to transcend narrow views that limit the drivers of extremism to religious fundamentalism and apologetics. Instead, this research illustrates the importance of understanding the historical dimensions of conflicts in societies, which influences conflict assessment to delve deeper into realising the role of historical traditions and ancestral orders, political systems, and the nature of pre-existing political grievances in shaping contemporary conflicts.

Using qualitative analyses, this paper reviews existing conversations on radicalisation and violent extremism by deconstructing both concepts and putting them in dialogue with conflict scenarios in Myanmar, and discusses the research's methodology and ethical considerations. Also, using a grounded theory approach, this research attempts to illustrate how structural liberation demands facilitate radicalisation and extremism among youths and presents some of the factors that enable their quest to accomplish subnational autonomy and ethnic recognition. Subsequently, the paper elaborates on the nexus between ethnonationalism and youth extremism, summarises the research's main findings, and offers a broad discussion that reveals the intersection of diverse causal factors that enable politically-motivated extremism in Myanmar, and elsewhere. This discussion contributes to the body of knowledge by showing how the nuances in the manifestation of radicalisation and violent extremism in Myanmar and elsewhere forces participatoryaction-research on the subjects to transcend single explanations of how the phenomena emerge or thrive across societies. This paper then presents some implications and recommendations of the research on the local environment in Myanmar. Consequently, this research makes two main submissions: first, a systemic and contextual assessment of violent extremism increases clarity and provides a nuanced understanding of the phenomenon, which then prevents the production of wrongly generalised forms of knowledge. Secondly, by addressing structural violence and ensuring institutional reforms, socio-political actors acknowledge pluralism and can, therefore, manage diversity to prevent ideologies that radicalise people.

\section{EXISTING DISCUSSIONS ON RADICALISATION AND VIOLENT EXTREMISM}

The debate on radicalisation and violent extremism has spurred interest from policy actors, governments, and academia globally. However, there are some challenges in reaching a comprehensive and universally accepted conceptualisation of these phenomena. This research clarifies that violent extremism has existed before its prominence in contemporary peacebuilding and security discourses. However, the complexity of factors that drives extremism currently forces different actors to rethink previous frameworks used to examine various forms of identity and ideological violence. Although there is relativism in conceptualising the notion of violent extremism and radicalisation, several attempts focus on asserting how individual and group feelings, societal structures and institutions, and trans-national and international alliances contribute to its prominence (Boyd-MacMillan, 2019; Stephens et al., 2019a; Stephens \& Stijn, 2019; Sageman, 2017; Shauri \& Wanjala, 2017).

Because violent extremism and radicalisation are complicated topics, contextualising the factors and theories that influence the emergence of ideologies that incite extreme violence remains pertinent towards developing strategies to manage or transform the phenomena. Therefore, focusing on a range of "upstream preventative approaches that position themselves explicitly outside of a security-driven framework" (Stephen et $a l ., 2019 b$ ) is critical to address extremism. These approaches should not follow a linear conceptualisation that focuses its understanding or strategies on a security agenda. Nevertheless, in a context where extremism manifests due to marginalisation, it should be treated both as security and development agendas. Therefore, conceptualising both phenomena in this manner offers opportunities for what Ackerman (2003) refers to as operational (short-term) and structural (long-term) prevention of violence. In essence, incorporating the varying social needs of various groups into the security and development agenda of a national peacebuilding framework offers opportunities to transform the attitudes and behaviours that cause the mobilisation of radical ideologies and extreme violence by non-state actors against a legitimate state.

In Myanmar, ethnic minorities lament the dismissal of their political concerns and the exploitation of their agency by the Central Government. The non-inclusion of minorities in the Central Government's makeup and the adoption of military repression to silence their political demands amplifies violent resistance and sustains violent struggles from ethnic liberation. As a diverse society, the need for ethnic minorities to become politically recognised and liberate themselves from state repression sustains ideologies of ethnonationalism. This ideology is also spurred by overlapping claims for territorial, resource, and population control. These overlapping claims underscore the variance between the diverse ethnic groups, and how these differences influence the political privileges 
that one group can enjoy compared to others. These experiences force ethnic groups to consider the control of the resources and populations under their sub-national domains as their responsibility, thereby challenging the country's Central Government's legitimacy to oversee the entire country's governance. Interview 26 asserted that "until the government and the military address the political structures that they have used to exclude ethnic minority tribes and divide identity in the country, the battle for liberating themselves may continue... in fact, we may just be in 'the beginning of the end'."

The continuation of political marginalisation of small groups by state authorities hold grave implications for governance, mainly when there is a low level of support from minority groups for the central state leadership. Lake (2002) posited that violent extremism attempts to provoke opposition groups into adopting disproportionate responses by radicalising moderates to support and accept their objectives in the long term. Nasser-Eddine et al. (2011) alluded to this position when they argued that "a willingness to use or support the use of violence to further particular beliefs, including those of a political, social or ideological nature" represents extremism. According to their claims, these agendas may include acts of terrorism. However, Mroz (2009) indicated that violent extremism represents a form of violence perpetrated without convincing justifications, mostly when the belief of committing acts of violence produces outcomes that outweigh the cost of human life. In the author's opinion, extremism includes homicide, genocide, fratricide, and, terrorism. Arguing further, Mroz distinguishes that "whilst terrorism can be countered, violent extremism cannot, as most forms of violent extremism are undertaken as 'lone wolf attacks' (whether as a one-off operation or as an operation undertaken by one individual)". By implication, acts of violence that cannot be curtailed through a security-driven method is not terrorism, and therefore, cannot be addressed. Contrarily, while the claims of Mroz hold some substance, this research argues that terrorism is often challenging to counter because the justifications for the perpetuation of global terror is vaguely presented. This ambiguity is hugely influenced by the fact that international terrorist alliances have individual and joint agendas that globally justify their terrorist attacks. These agendas are often [mis]aligned with one another depending on each terrorist cell's interests and alliances.

Equally, violent extremism could emerge out of resentment, which has not been constructively addressed or resolved; therefore, necessitating a resort to violent actions to achieve the change that is sort. While in the case of terrorism, the only actions adopted by states to counter acts of terror is securitydriven, violent extremism can be countered within different environments when the "structural, attitudinal and transactional" (Ricigliano, 2012) drivers of violence are adequately understood. These efforts could involve addressing the institutional sources of grievances and disparity in society. Hence, adopting both security and preventative approaches to countering radicalism and extremism will produce positive results. This understanding refutes Mroz's propositions, which are subjective, formulaic, and dismisses the possibilities that many states that perpetuate or support extreme use of violence that negate international best practices could be perpetrating state-sanctioned terrorism. Therefore, framings like those of Mroz empowers some states to proscribe specific groups as extremists or terrorists while they are also guilty of unjustly employing disproportionate force on civilian populations. Mroz's articulation validates the deplorable treatment that the Rohingya tribe currently receives from the Tatmadaw in Myanmar's Rakhine State because of the perception that this predominantly Muslim ethnic group constitute a significant threat to ethnic Rakhine tribes and Buddhist-nationalism in the country.

To create more nuance about radicalisation and extremism, Nasser-Eddine, et al. (2011) claimed that terrorism is part of the broader violent extremism phenomena, and often has a broader link with Islamist Jihadi agenda. Even though their claims are valid, the definition of terrorism needs to distinguish the forms of extremism that metamorphose into terrorism, and how these typologies influence individual and collective participation in terror globally. Besides, although there is interplay of factors between diverse forms of extremisms and how they influence the conceptualisation of terrorism, terrorism needs to be debated as a somewhat distinct security dilemma that threatens global peace. By hinging radicalisation and extremism on religion alone, we validate specific communities' categorisation as terrorists. Terrorism is an act that is voluntarily indulged and perpetrated by individuals who support the agenda of specific terrorist organisations. Therefore, even though violent extremism exacerbates violence, not all extremists are terrorists. When violent extremism is contextualised based on the realities in different societies, its manifestation is better understood and easily resolved.

Meanwhile, several authors have argued against a policy-led conceptualization of violent extremism and radicalisation that relates both problems to Islamist Jihad because it stereotypes specific communities, and impedes opportunities of reaching a well-articulated theoretical framing of the phenomenon. The adoption of policy-led conceptualizations of these problems inspires the development of several theories and programmes that are based on assumptions but lack comprehensive and convincing empirical evidence (Liden, 2018; Mušić, 2018; Hardy, 2018; Glazzard, 2017; Bowen, 2017; Luengo-Cabrera \& Pauwels, 2016). Mušić (2018) noted that when violent extremism and radicalism is associated with religion, it is portrayed in two primary forms:

... first, the radicalism induced by the violent, rigid and reductive understanding of religious teachings (which can lead to the emergence of sects, enslavement, and movement)... the second, radicalism inspired by external, i.e. non-religious motives (winning political support, poverty, repressive state politics, marginalisation, injustice, violation of rights, media 
propaganda, etc.). Both forms can be turned into acts of violence that, in order to morally justify, they are trying to "muddle" under cellophane religion (this is mostly done by ideologies).

Following this assertion, the justifications for inciting extreme violence does not necessarily originate from theological teachings or dogmas. Instead, religious justifications are decontextualised to offer alternative interpretations that fit into populist definitions of violent extremism. Hence, because religious ideologies are sometimes superficial, different forms of abused understanding of religious tenets emerge to support or justify the parochial interests (usually political) of actors who seek to weaponise it for violence (Mušić 2018; Borum, 2012). While violent extremism's root cause may not be religious, it is often a strategic instrument through which vulnerable individuals are mobilised to express group grievances. These experiences sometimes sustain the assumptions that specific religious communities are dangerous, thereby relegating such groups' the general agency.

Consequently, classifying groups as extremists demonstrates the subjectivity of 'who' has the prerogative to judge an opponent as good or evil, particularly when one group's extremism could be another's liberation struggle such with the case of the Mujahedeen resistance of the Soviet Union's occupation of Afghanistan between 1979 and 1989. While some states engage in different forms of violence against perceived enemies, without demonstrating accountability for their actions, others who have exhibited the same violations have been called-out and proscribed by international organisations. It is noteworthy that violent extremism could become an excusable device to demand political change when state repression of weaker groups exists. Therefore, it is crucial to clarify that the description of extremism should discuss how specific contextual and structural factors influence the formulation of narratives that become rallying points for inciting violence or large-scale insurgency. For instance, the adoption of 'political' violent extremism may emerge from a desire to undermine state authority or oppose the dominant rhetoric of recognised actors whose actions oppress some citizens. The essence of these actions is to establish significance, legitimacy, political liberation, and disrupt the socio-political opportunities that empower opposition states from continuing its violent agenda.

Meanwhile, Hardy (2018) argument summarises the thoughts of several authors on the subject. He asserts that radicalisation and extremism are influenced by ideological, psychological, social, political, economic, and technological factors. He explains that several kinds of literature on extremism expose how people radicalise, but not why. It is both necessary to understand 'why' and 'how' people radicalise because the former provides clarity and justifications for the mobilisation of violence and how it becomes sustained as a means of achieving personal or group goals. Besides, the latter explains the pathways that are employed towards mobilising support to achieve an end goal. Hardy further mentions that "cognitive radicalisation depends upon the idea that a person internalises extremist idea on their path towards violent action". In essence, narratives that will radicalise people and invite them for violence are first internalised before they are acted out. However, it is noteworthy that not all radical or extremist ideas resonate with a person or group, especially when it does not validate their experiences or ideological or physiological needs. Instead, the most salient justification for adopting such ideologies could be due to pressure from friends, family or other alliances to which people belong. The relationship among relatives, friends, and other peers may encourage a "group phenomenon", where individuals internalise and adopt a shared mindset, which is exerted through manipulation, persuasion, or coercion (Hardy, 2018; Maskaliunaite, 2015; Lakhani, 2012). The influence that group members have on one another is sustained when they seek to satisfy their quest for meaning by exploiting their psychological needs as justifications for becoming radicalised.

\section{METHODOLOGY AND ETHICAL CONSIDERATIONS OF THE RESEARCH}

This research considered ethics as an essential part of the design, sub-structure, and process of administration. Since the research design required collecting primary data from human subjects in Myanmar, the researcher submitted a research proposal for review and approval by the Institutional Review Board (IRB) at the University of Notre Dame in the United States. Also, to ensure that the research adapted and maintained best practices in protecting human subjects and their information, it adhered strictly to the tenets of the Belmont Report. These tenets include "respect for persons, beneficence, and justice" (Belmont Report, 1979). Individuals who are over 18 years of age and could give informed consent formed the research population. The researcher ensured that interlocutors' engagement in the research was voluntary, with consent remaining an ongoing conversation throughout the research.

A total of thirty (30) in-depth interviews were conducted with members of civil society organisations, youth-led non-profits implementing social cohesion programmes, former political prisoners, activists, student organisations, representatives of some EAOs in the National Ceasefire Agreement (NCA), independent researchers, and other independent voices in order to answer the research questions. This approach was complemented by participant-observation and listening methodologies to ensure a clear grasp of political extremism issues that people articulated. The responses are analysed in a disaggregated and conversational format rather than in an aggregated form. Also, a desktop review of the existing literature was conducted to complement the collected primary data. The entire duration for collecting on-the-ground data for this research was six months - July to December 2019. 
Violent Extremism and the Structural Liberation Theory in Myanmar:

This research develops a 'different' (not new) grounded theoretical model for understanding radicalisation and extremism. The theory of structural liberation builds on three existing conflict theories: relative deprivation, frustration and aggression, and the quest for significance. Based on the research respondents' feedback, this grounded theory examines the emergence of radicalisation and violent extremism as a product of unmet political needs. These unmet needs spark the creation of besiegement narratives and the use of violence as a way of seeking freedom from a repressive "other". It reveals the significance of granular mapping of different needs and feelings that resonate with the structural, attitudinal, and transactional drivers of conflicts within societies. This model identifies and understands the psychological (or cognitive) and physical (or material) incentives that inspire radicalisation and extremely violent behaviours. The relative deprivation theory posits that when an individual believes that $\mathrm{s} / \mathrm{he}$ is deprived of something they deserve by comparing themselves with others socially, politically, and economically, adopting dysfunctional methods to display dissatisfaction is likely inevitable. The more individuals or groups score their socio-economic performance to be comparatively low when juxtaposed with other members of society, their susceptibility to extremism is relatively high (Nasser-Eddine, et al., 2011; Al-Lami, 2009).

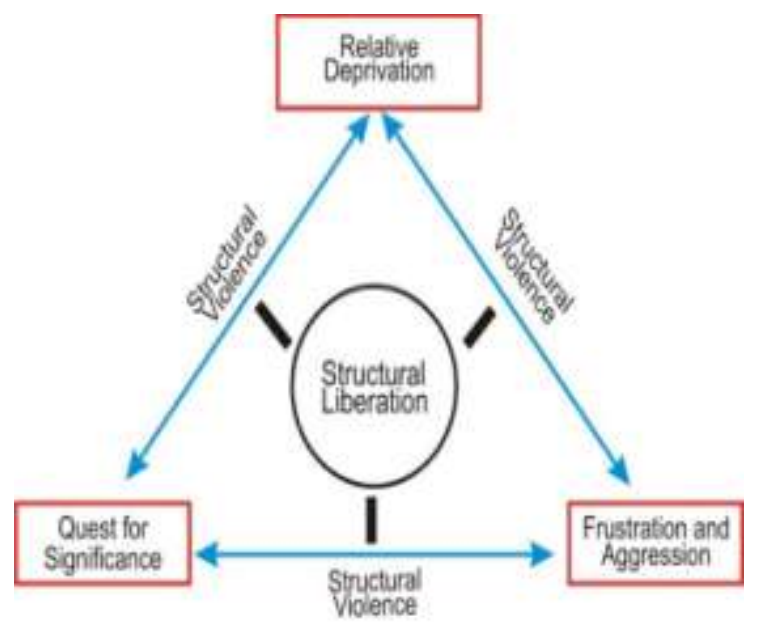

\section{Structural Liberation Triangle}

More so, these feelings of deprivation further stir "aggressive actions, which are directed towards the perceived sources of frustration" (Zillmann \& Cantor, 1976 cited in Breuer \& Elson, 2017) in a manner that is violent and retaliatory, demonstrating the social imbalances that people feel. Therefore, "the greater the imbalance, the weaker the constraints imposed by the suppressed needs, and the greater the perceived acceptability or legitimacy of extreme or unusual behaviours" (Kruglanski et al., 2018). These retaliatory behaviours expose grievances and make groups portray themselves as significant actors whose concerns should not be undermined. Interview 28 reinforced this point when he explained that "minorities suffer because of structural violence. The type of systems that society creates and operates either reduces suffering or increases it. But if it increases pain on specific groups, we can't rule out the possibilities of opposition when people become aware." Hence, the legitimacy of politically-motivated extremism forces actors who possess recognition within their immediate identity groups to mobilise an agenda that reflects their constituency's suppressed situation. Such agendas are usually "rooted in personal experiences and the quest for collective significance rooted in the perception that one's social group is humiliated or disrespected" (Jasko et al., 2019). The definition of 'significance', in this case, involves a group's quest for political recognition by asserting their relevance and influence in determining political outcomes within a broader sociopolitical system.

Therefore, the theory of structural liberation posits that protracted feelings of grievance within a marginalised social group(s) instigates the creation of radical narratives to mobilise support for political extremism against repressive socio-political systems that prevent collective thriving. These grievances are usually associated with a group's unmet sociopolitical needs, which then necessitates political liberation demands. Demands for political liberation are intended to empower them to attain significance and make decisions that affect them directly. The creation of these extreme narratives along the lines of deprivation, disrespect, dehumanisation, insignificance, and socio-political differentials between 'them' and 'others' enables radicalisation and extremism. Within the context of this theory, the use of ethnonationalism, as a liberative political agenda, to radicalise people is established. However, as a caveat, this research clarifies that while this theoretical model helps understand youth extremism in Myanmar, it may hold limited explanatory power for the phenomenon in other environments. However, it could offer a broader lens with which structural violence and other socio-political and religious factors constitute drivers of violent extremism. This in-depth assessment helps distinguish the links between social, political, economic, or identity factors that contribute to radicalisation and extremism within societies or specific populations.

In Myanmar, previous authoritarian regimes suppressed democracy and ethnic autonomy over the years, contributing to political extremism and conflict escalation in different ways. This repression is also reflected in the imposition of 'defined national framing' for identity throughout the country. This forced identity further increases structural violence; a circumstance that Galtung (1969) describes as the extent to which different systemic oppression tools become internalised by repressive structures against specific groups so that personal violence becomes institutionalised as norms. Such imposed identity increases one group's political leverage over another, thereby widening the gap between different 
ethnopolitical groups. For instance, the perception that Burmanisation - an ethnonational socio-political agenda that emphasises and prioritises Bamar-Buddhist values - is imposed by Myanmar's government, which is Bamardominated, threatens the identity of ethnic minorities and widens inequality among diverse ethnic groups. This ethnocentric/ethnonational ideology privileges the Bamar ethnic group politically, economically, and socially. It is upon this political ideology that Myanmar's military - also called Tatmadaw - develops and engages a repressive strategy against other ethnic [armed] groups across the country and seeks to transition Myanmar to 'complete democracy'. A complete democracy, in this sense, refers to a civilian-led system of government that accommodates military participation in civilian processes of decision-making on national issues. Interview 7 ellobarated that "ethnonationalism is gaining support because Burmanisation shows what Barma people want. It is their understanding of politics, and they want to force other ethnic groups who do not like it to accept it... if they [ethnic minorities] don't accept it, then they will develop their own (ethnonational ideology)."

Following Myanmar's government's repressive tactics and the tacit exclusion of ethnic minorities from national politics, many ethnic groups replicate ethnonational ideologies as ways to self-identify and garner support from their ethnic groups. Ethnonationalism divides local populations and spurs the use of violence by ethnic tribes to display political discontent. While the country's history is characterised by identity and ideological violence, ethnic groups remain sharply divided and continue to proliferate demands for political recognition due to the Central Government's perpetration of structural injustices. These ideologies are transferred across generations, with youths being the principal recipients of these radical ethnic philosophies. The justifications for transferring these ideologies is to ensure that youth in ethnic minority areas continue to resist hegemonic socio-political systems and achieve liberation for their ethnic group. Hence, the rhetoric of ethnonationalism invokes an obligation to use violent resistance to achieve ethnic liberation, since several constructive options have failed to produce substantial outcomes.

Some of the structural factors that escalate conflicts in Myanmar are complicated and kaleidoscopic. They embody discriminatory characteristics that privilege the Bamar ethnic group over other ethnic minorities, thereby inciting demands for structural changes by repressed ethnic groups. This research summarises three causal factors that enable violent extremism and demands for structural liberation by ethnic minorities.

\section{Weak Political System and the Contested Legitimacy of the} State:

Governance in any society is dependent on the type and strength of political systems that they operate. These political structures create the bedrock for citizen-centred leadership and the delivery of democratic dividends, particularly when they are designed to be inclusive. Chalk (2013) elucidates that exclusionary politics in Myanmar are driven by weak institutional capacity, a governance system that lacks broad acceptability, accountability and transparency, a Central Government that is allegedly ethnocentric, and competing political interests and power play by ethnic elites. Similarly, Williams (2015) expresses pessimism in Myanmar's political system when he opines that the country's "transition from military rule to democracy is far from complete, and its successes to date remain fragile". For instance, the constitution developed in 2008 bestowed the Tatmadaw with a guardianship role and full autonomy alongside the civilian government, thereby creating a hybrid system of government. Therefore, following these constitutional powers, the Tatmadaw assumes a political role in civilian affairs because it controls three significant ministries in the Central Government's cabinet (Defence, Home Affairs, and Border Affairs) and occupies twenty-five per cent of all parliamentary seats.

These three government institutions are essential because they require a high level of experience and skill to manage, which the Tatmadaw most likely possesses. However, controlling these institutions is part of the military's strategy to remain in civilian affairs and influence some of the civilian government's major policies, thereby protecting their interests. The cumulative effects of these political privileges tacitly grant them significant power over any constitutional changes. However, Myanmar's political makeup's fundamental questions are: which political/ethnic group is legitimate at the national and sub-national levels? In whose eyes? (Egreteau \& Mangan, 2018; Stokke et al., 2018). These unanswered questions justify why many EAOs constantly challenge the Central Government's authority and the power assumed by the Tatmadaw. Besides, due to the unclear roles of ethnopolitical actors and the political institutions' legitimacy, the claims of uncertainty for an improved polity in Myanmar is valid. Such positions' validity is amplified by the dictatorial design of the country's transition processes to democracy by the Tatmadaw.

On the other hand, EAOs assume that their control of small swathes of territories and provision of essential services to ethnic populations garners support for their agenda, and increases their political leverage. This assumption follows their resort to regional insurgency after the central government (and Tatmadaw) continually failed to implement political commitments, particularly those from the Panglong conference and the 2010 ceasefire agreement (ISDP, 2018). Although there are instances of state-rebel collaboration in Myanmar's sub-national conflicts (Staniland, 2012b), several pieces of evidence reveal that the hybrid systems of control across conflict regions and the protracted ceasefire arrangements resulted in locally negotiated agreements that specify the perimeter of operations of different armed actors in proximity to one another. Through these implied systems of 
legitimacy, EAOs leverage their political and military capacities to collect taxes, provide services, and institutionalise emblems (such as flags) to represent the political identity of ethnic tribes (Jolliffe, 2015; Jolliffe, 2014) and consolidate their political relevance.

Furthermore, it is crucial to highlight that the contest for state legitimacy in Myanmar emerges partly because ethnic minorities feel undervalued by the central government, despite having historical legacies of successful political authority and institutions in ethnic areas. Myanmar's weak political institution is also influenced by the existence of a political infrastructure that was one of the world's most reclusive for over half a century until the country's current process of transition towards democracy (Seith, 2018; Williams, 2015; Renshaw, 2013; Chalk, 2013). This reclusive political infrastructure opposed plurality but maintained military highhandedness as an effective tactic for controlling political affairs. The protraction of violent conflicts because of military rule also impeded robust diplomatic efforts to mediate the conflicts and support early actions to strengthen the capacity of political institutions. In addition, the political inconsistencies, complex interests and identities, and growing demand for self-determination affect institution-building efforts in the country. Therefore, to improve the legitimacy of political institutions in Myanmar, implementing reforms is compelling to encourage competitive and vibrant governance systems that allow for constructive opposition and multipartisan approaches to addressing collective political concerns.

\section{Bamar-dominated Central Military and Public Institutions:}

An essential element of a well-governed public sector is that it is participatory and inclusive, reflecting effective representation of all groups domiciled in a state. Representative public institutions and security services prevent domination by specific groups and increase public confidence in state authorities. However, when there is a deficient level of diversity in civil service and law enforcement in society, perceptions that nepotism and cronyism underlie the participation of identity groups in these institutions grow. These actions, therefore, portrays the existence of exclusionary national identity in the public sector, weakens the administration of the rule of law, and encourages discriminatory public service. Interview 17 accounts that "Myanmar's problems started since after independence; ...the Barma ethnic groups have remained in power and did not really allow the inclusion of minority ethnic groups into governance in the country. So, the conflicts between the EAOs and the government is because they are struggling for political power." The ethnicisation of the civil and security services in Myanmar deepens resentment because the Bamar ethnic group also dominates these sectors. This domination enables the advancement of Bamar socio-political ideologies and values (Burmanisation) in governing the country. The inadequate inclusiveness of ethnic minorities in these sectors further marginalises and dismisses their contributions to public institutions' design, growth and sustainability. Historically, the challenge of domination by the Bamar ethnic group overwhelmingly empowered military consolidation of power in civilian institutions because they controlled and appointed the leadership of public institutions between 1962 88 (Burke et al., 2017).

Furthermore, as part of the transition process to democracy, aiming for security sector reforms should be among the top priorities of the country's central authorities. These reforms should adopt cross-cutting engagement of diverse identity groups, civil society, private and business sectors, and members of disbanded ethnic militias. However, such reforms appear to be elusive following the Tatmadaw's dictation of the terms for EAOs to become Border Guard Forces (BGFs) allied militaries of the Tatmadaw - in the 2015 Nationwide Ceasefire Agreement (NCA). Although Myanmar's central government seeks to institutionalise its legitimacy, the epistemological interpretation of their actions appears to reinforce the Tatmadaw's hegemony tacitly and dismisses inclusivity as a viable means of achieving collaborative changes in the security sector. Egreteau and Mangan (2018) explained that the Tatmadaw's reluctance to exercise initiative and improve the effectiveness of dialogue platforms with all the EAOs to design a roadmap for security sector reform affects peace in Myanmar. This behaviour is mostly associated with its centralisation of decision-making, which is characterised by directives rather than consultations.

Considering historical mistrust between ethnic minorities and the central government, a focus on the reformation of the security sector to be more diverse is vital to boost civilian confidence in state institutions. The country's security sector should consist of an agenda that encompasses traditional civilmilitary collaboration and coordination towards addressing security-related grievances and broader insecurity. By implication, security sector reforms should genuinely focus on the following: recruiting and reintegrating all armed actors from different ethnic groups into a central security apparatus; re-direct the goal of security from being state-centric to focus on human security (Schirch, 2018; Cortright et al., 2017; Hendrickson \& Karkoszka, 2002); and prioritise the contributions of civilian actors in formulating security policies and frameworks (Hendrickson \& Karkoszka, 2002). Inadequate consultations with EAOs and other civilian actors in the Tatmadaw's security decision-making raises doubts about its genuineness to completely hand-over power to civilians in a democratic transition process.

Socio-economic Inequality and Control of Natural Resources:

Myanmar is ethnic diverse. While cultural diversity in many other parts of the world is often referenced for contributing to the construction of a collective national identity, it challenges peaceful co-existence in Myanmar. While identity plays a critical role in displaying the political relevance of ethnic groups, territorial and resource control strengthens the political and military capabilities of EAOs to consolidate 
power sub-nationally. Many citizens in Myanmar suffer a significant level of socio-economic discrimination because the Tatmadaw seeks absolute resource-control. From instance, growing economic inequality sparked protests by labour unions and public workers who were demanding a review of the current minimum wage from KY4,800 (\$3.26) to K9,800 (\$6.66) (Tun \& Soe, 2020). Socio-economic inequality in Myanmar contributes to poverty, political exclusion, and affects adequate access to government-owned social services. Beyond gaining legitimacy, the nature of inequality faced by ethnic minorities in Myanmar also attests to why social services provided by EAOs increases their acceptance by some members of the local populations in the sub-national areas that they control. Visible patterns of inequality among citizens fuels frustration and contributes to factors that aggravate discontent among ethnic minority tribes.

In addition, although Myanmar is rich in natural resources such as timber, gemstones, oil and natural gas, and hydropower potentials, these resources which are situated in ethnic areas, especially those controlled by EAOs, stir economic interests between the different armed actors - i.e., EAOs and the Tatmadaw. These natural resources also offer high potentials for the country's economic growth; perhaps, they also contribute significantly to the challenge of governance. Control over natural resources and the different trade routes generate economic resources for the central government and EAOs to continue service delivery to their different populations and sustain [counter] insurgency (Burke et al., 2017). Callahan (2007) revealed that natural resource control "gradually allowed for the formation of multiple territorial pockets growing outside of central state control". This continuous contest empowers the legitimacy of several smaller power-holders controlling sub-national areas, thereby weakening the Central Government's authority (Callahan, 2007). The relegation of the central government's authority in these EAO-controlled areas also stems from the political and social imbalances those ethnic minorities feel is perpetrated against them. The state-like structure assumed by EAOs consolidate this position. This research clarifies that the centrality of ethnic grievances in Myanmar lies in the political right to self-determination, which empowers ethnic minorities to influence political outcomes against praetorian authorities. Without facilitating inclusive actions to achieve participatory economic opportunities and security provision, the sustenance of individual ethnonational ideologies across the different ethnic groups to radicalise people, incite violence and demand structural liberation remains inevitable.

\section{ETHNONATIONALISM AND YOUTH EXTREMISM IN MYANMAR}

Myanmar has witnessed over seven decades of protracted conflicts; tensions that emerge due to multiple factors that are complex and intractable. These factors reveal the complicity of many actors in the escalation of human suffering by destroying livelihoods, violation of human rights, increased death toll, and human trafficking, among other outcomes.
Although conflict drivers in each part of Myanmar are peculiar and unique to the regions, one feature that resonates with all the conflicts across the country is "ethnicity". The affinity to ethnic identity by citizens is strong, especially with the need to strengthen the socio-political agenda of each tribe. Thus, strengthening the legitimacy of and amplifying various ethnic voices' demands inspire ethnonationalism ideologies to advance political demands, radicalise people, and mobilise group participation in extremism. Although fundamentally distinct in terms of understanding across various ethnicities, ethnonationalism represents rhetoric that describes the importance of self-determination by ethnic groups and liberation from structural injustices perpetrated by the Central Government (Bynum, 2018; Egreteau \& Mangan, 2018; Jaquet, 2014). Using three sub-themes, this section x-rays how ethnonationalism and other factors influence political extremism among youths in Myanmar.

\section{Framing of Identity and the Paradox of Allegiance:}

Ethnonationalism in Myanmar is complex and deeply problematic because of the historical antecedence of conflicts and how ethnic identity has become polarised. The polarisation of these complex identities creates competing systems of authority that are ambiguous. However, assessing the multiple perspectives of actors engaged in escalating violence in the country provides nuanced knowledge of how the concept cements minority ethnic groups' power and facilitates their maintenance of a significant degree of autonomy from the central authorities. The concept of ethnonationalism is closely linked to a quest for significance, which emerges from political exclusion, betrayal, frustration, and the struggle for liberation and power. It provides a rallying point for mobilising rebellious [armed] actions that sustain extremism and conflict escalation.

Ethnonationalism represents a nationalistic, separatist, and liberalist ideology. Depending on the interests of diverse ethnic actors, ethnonationalism has varied meanings among local populations. While it demonstrates loyalty to one's ethnic group, the concept is also an agenda through which many ethnic minority tribes demand political legitimacy. Depending on the social context of ethnic groups, extremely marginalised ethnicities consider themselves to stand a higher chance of achieving their political goals when they selfdetermine. Interview 7 narrated that “... people believe that they are responsible to their ethnic group. They want freedom; they want their own federation; they want their own authority... this is why many youths in rural areas have access to join the EAOs". Interview 14 reinforces this point when she mentioned that "...in Myanmar, people see violence as fair. As young children, we are told and trained by our parents not to allow anyone who beats us to go free. We must always win all fights! We [children and youth] internalise this training, and it has become a part of us. How then can you change us from such a mentality?" 
The need to defend one's ethnic group is not only tied to seeking significance but embedded in understanding how ethnic identities were created historically. It reveals how ethnic allegiance influences the formulation of relationships and ethnic interactions across the country. Interview 27 asserted that "...people want their authority; they want their government, and that is why they have to participate in their ethnic liberation struggle". These claims reveal growing concerns among ethnic minorities that the central government does not adequately prioritise their political needs. Ethnic minorities consider such attitudes as a governmental failure that necessitates the creation of 'alternative territorial governments' that can address constituency needs. Creating rhetoric around the importance of a 'new independent government' from an existing state demonstrates a clarion call to rebellion; one that is not easily ignored when there is a collective feeling of frustration.

South (2009) noted that "the emergence of ethnic identity in Myanmar has a politically salient characteristic" that is difficult to establish in a concrete definition because of its sophisticated understanding and application among ethnic groups. Interview 28 noted that "ethnonationalism gives ethnic groups a desire that they can drive and determine their future... it is an inspiration that you can be significant by yourself and make decisions that affect your people... people want to join their ethnic armies because they want to get their own country." While Interview 28's description may not reflect the general perception of all peoples in Myanmar, this research debates that the construction of ethnic identity and its significance within the broader country signifies the level of allegiance of different ethnic members, and informs how such commitments are leveraged or manipulated to radicalise people and fuel violent resistance. According to Gravers (1999), as cited in South (2009), "in traditional Burmese society, identity was determined by (a) whether one was Buddhist, and (b) whether one was a member of an alliance with the ruling dynasty... with the key to the fulfilment of patron-client obligation being power..." Consequently, the categorisation of ethnic identity in Myanmar has a historical antecedence, providing justification for the current political power play. It also demonstrates how the wielding of relative strength by specific ethnic constituencies cements their ability to influence leadership and extreme violence within society.

The weaponisation of ethnonationalism as a political tool also reveals the gaps embedded in the process of transition from colonialism to independence. Taylor (2005) recorded that Myanmar was never adequately integrated administratively as one Union by its British colonialists. Instead, the powers that many local political elites in lowland regions possessed were further used to organise their immediate constituencies and maintain significance, rather than reduce the scope of colonial separation. Disrupting the idiosyncratic nature of identity would have fostered a stronger sense of pan-Burmese identity. Besides, colonial rule ossified the loosely structured sociopolitical arrangements among tribal people in mountainous regions (South, 2009), thereby providing clarity to the sources of factionalism, competing ideologies for significance, socioeconomic disparities, and repulsive attempts to totalise 'nationalism' without addressing fundamental political gaps that are historical.

Even though ethnonationalism in Myanmar is difficult to deconstruct, its characteristic emergence as a radical ideology demonstrates that historically unaddressed socio-political needs among minorities stir resentments that are transferred across generations. This transfer of frustration causes the meaning of such radical ideologies to continually mutate into more complex, unexplainable, and likely incomprehensible concepts, which then sustains new forms of violent extremism. These grievances also sustain the proliferation of factionalised politics that create new ideologies around ethnicity or other forms of identities (such as Buddhist nationalism) to complexify violent extremism and conflict escalation further.

\section{Exclusionary Politics and Disillusionment:}

Following the end of World War II, Burma became an independent nation from Britain in 1948. Before independence, General Aung San sought to unify the country by inviting most ethnic nationalities (which were quite semiautonomous territories within Burma) to the Panglong conference. This event is attributed to have birthed the formation of the Union of Burma. The participation of ethnic nationalities in this conference was on the premise that larger ethnic groups like Shan and Kachin will become fully autonomous in their internal administration, and receive equal participation and share in the country's wealth and political resources. However, with General Aung San's assassination, successive military governments failed to deliver on these promises. Instead, they use repressive tactics to oppose different ethnonational minority groups caused a resumption of hostilities (Clarke et al., 2019; Buchanan, 2016; Jaquet, 2014). Thus, understanding the country's history is critical to resolving its political issues and creating peace trajectories.

While Myanmar struggles with highly protracted and militarised conflicts that date back to pre-independence, the desire to transform conflict relationships and transition the country towards peace is pursued using political negotiations. However, several ceasefire agreements collapsed because actors, especially the Tatmadaw, did not honour the commitments in these agreements. For instance, the ceasefire agreement, which granted some regions of Kachin State political autonomy, was maintained between 1994 and 2011. Although this agreement provided ethnic nationalists from Kachin the opportunity to participate in the National Convention that resulted in the drafting of the 2008 national constitution, many ethnic representatives claimed that their inputs were not significant, neither were their grievances addressed in the newly drafted constitution (Burke et al., 2017; Davis, 2016; Jolliffe, 2015). The consistent renege on political agreements by successive Central Governments 
weakens trust and confidence among ethnic minorities. Also, the prescription of a political roadmap to democracy that is 'disciplined' and focuses on building a system that protects the Tatmadaw's interest is highly problematic, contributing to the deepening of political hardlines by EAOs and minority ethnic groups (Cuesta, 2016). When specific ethnicities that constitute the majority of a broader population set out parameters that will determine an entire country's sociopolitical trajectory, the proliferation of extremism is likely to escalate. In post-conflict societies, institution- and peacebuilding decisions that support the institutionalisation of democracy should emerge through participatory processes that incorporate all social actors' voices, including those affected by violence. Interview 8 narrated that:

For me, inter-communal clashes are just a distraction tactic that the Myanmar military uses to distract EAOs from fighting back at them... although we [youth] can demonstrate peacefully in our communities to ensure that all members come together to achieve a common goal (self-identity), we cannot demonstrate or dialogue with the government; we use force. Violence is the best language that the Tatmadaw understands... Ethnic minorities are excluded politically, and there is no plan to change things; so, the way to liberate ourselves is to fight... We can't take it!

With conflict actors reaching an impasse on several occasions over conflict de-escalation, communities continue to face a two-fold manifestation of the outcome. First, the increased militarisation of communities by armed actors (whether EAOs or the Tatmadaw) exposes communities to high levels of insecurity, abuses (sexual, physical, and psychological), and increases political economies. Secondly, inter-communal conflicts will continue to escalate as smaller criminal groups emerge and leverage on the proliferation of small arms and light weapons to perpetrate other micro-forms of terror. If deprivation and exclusionary politics continue in Myanmar, the proliferation of armed organisations cannot be overruled. By implication, the radicalisation and recruitment of more youths as ethnic fighters becomes sustained as a strategy for mobilising new generations of armed ethnic resistance.

Throughout the country, the overarching demands for political legitimacy are consistent in regions like Shan, Kachin, and many other parts of the Southeast of Myanmar. This desire motivates the maintenance of political hardlines that deepens the complexity of the conflicts. Even though the NCA exists, the journey towards transforming Myanmar's conflict relationships remains obscure. Although the NCA is required to provide a constructive path away from the conflicts and address political issues, some armed groups were either deliberately sidelined by the Tatmadaw or refused to participate in the process because they did not accept the hegemonic 'terms of participation' (Emah, 2020; Davis et al. 2016). This type of action gains significant traction because the legitimacy, capacity, and effectiveness of the state and different non-state power brokers vary throughout the country.
Varying degrees of power that different actors wield creates fluctuating responses to the impact of the conflicts, including taking absolute control of the economic resources present in different regions of the country. Thus, the diverse power dynamics at play in the conflict exposes state fragility in Myanmar. In addition, considering the multi-party nature of the conflicts and the alleged high-handedness of Myanmar's central authorities, transforming the conflicts and reaching beneficial outcomes remains near impossible. Due to the impasse between the Tatmadaw and many EAOs, reducing the negative impacts of the conflicts on local populations and the entire country remains a relatively ambitious process.

\section{The Politics of Religion and 'The-China-Effect':}

The theatre of violence in Myanmar challenges the assumption of many populists' opinions about extremism and radicalisation. It forces peace researchers and scholars, practitioners, and policy actors to understand the intersection of several structural factors that creates asymmetry among various identity groups. It enables our understanding of how the interplay of power dynamics can relegate one group's identity but empower another. The politicisation of ethnicity in Myanmar impedes the construction of a nationally-accepted identity. This conundrum is accompanied by an unfair distribution of national wealth and political power, access and delivery to social services, stereotypical relationships, and the presence of weak state institutions with complicated and discriminatory modus-operandi. As a multi-cultural society, these challenges further widen the relationships among ethnolinguistic and religious groups, whether they are indigenous or not, and shows the interplay of various factors that influence the framing of narratives around political struggle and power contests (Egreteau \& Mangan, 2018; Wells, 2016).

Although ethnonationalism sits at the heart of the conflicts in Myanmar, the politicisation of religion through anti-Muslim sentiments, fueled by Islamophobia, contributes to the complexity of the conflicts. For instance, during elections, the development of religious propaganda by politicians and the Tatmadaw to incite violence against Muslims appears to be both a perceived and real distraction from the structural issues facing minority tribes. With many extremist Buddhists monks inciting and buying into anti-Muslim narratives, it can be argued that such religious leaders lost their moral authority and have become co-opted by discriminatory political elites who leverage historical disparities between Buddhists and Muslims to escalate identity conflicts. More often, the resurgence of Buddhist nationalism has been accompanied by anti-Muslim sentiments, with associations like "the 969 and the Association for Protection of Race and Religion (known by its Burmese acronym, MaBaTha) spearheading campaigns to protect Buddhism against perceived threats, including Islam". This countrywide anti-Muslim sentiment has increased physical attacks against Muslims as well as their discrimination from national affairs. These stereotypical narratives are popularly accepted by Buddhist extremists in 
Myanmar, making it politically difficult for the central government to make decisions that are perceived to support Muslims (Kyaw, 2016; ICG, 2014). It is noteworthy that while religious ideologies are significant for radicalisation and inciting extremism, the social landscape in Myanmar prioritises ethnic affiliations as a primary means to achieve political control. Besides, Buddhism is a complementary factor that further cements acceptability within political circles.

For instance, in Rakhine State, Simbulan (2018) asserted that the growth of Rakhine ethnonationalism negatively impacts relationships and conflict dynamics between 'Stateless Muslims' and ethnic Rakhine. More so, "the promotion of a besiegement narrative that ethnic Rakhine is under attack by stateless Muslims has weakened inter-communal relations with Muslims and led to the emergence of social policing within Rakhine communities aimed at discouraging positive interactions" (Simbulan, 2018). Interview 1 revealed that “... Muslims are not the problem; neither is Islam... Many youths that escalate anti-Muslim sentiments are mostly already radicalised and are frustrated because of the political deprivation of their ethnic groups. Religion is just another weapon used by politicians to further polarise identity in Myanmar; but the truth is, the military has orchestrated things this way." Interview 7 mentioned that:

using religion as an instrument to mobilise Buddhist against Muslims is terrible. They [government] make it appear like the Muslims are the problem, especially when they link Islam to ISIS and terrorism. Islam has been in Myanmar since the colonial period, and so it is unfair to generalise Muslims as terrorists. In my opinion, it is just a political distraction that many youths who refuse to study history have bought into. The Bamar-led military is shifting public attention from what is happening out there and trying to use religion to pit citizens against one another... Those Buddhists who fuel this ideology are also extremists...

Interview 1's position ostensibly resonates with ICG's (2014) report that noted how citizenship law in Myanmar discriminates Muslims and impedes their chances of becoming full citizens. Due to the ambiguity of Myanmar's citizenship law, it is difficult for many citizens, especially ethnic minorities and Muslim communities, to access citizenship. While some ethnic minorities face challenges to become citizens, the restrictions are stiffer for Muslims. Muslim communities, particularly the Rohingya, face significant restrictions on their access to citizenship, with most of them confined to concentration camps instead of being integrated into the broader society. Structural restrictions on acquiring citizenship have significant impacts on their rights and ability to obtain government services. Thus, it is evident that the upswing in the weaponisation of religion, as a distractive tactic, may demonstrate the Central Government's unwillingness to address structural injustices through inclusive reforms, increase frustration among ethnic minorities and amplify cynicism about a possible transition to just peace.

Subsequently, geopolitical factors and the interests of the international community also impact the conflicts. Myanmar's conflict, which is a combination of ethnonationalism, humanitarian needs, and under-development, has China playing a crucial role in its escalation. China allegedly influenced the Burmese government's refusal of external support, especially from the United Nations, to mediate the conflicts. Instead, China offers to play the mediatory role as a continental giant in the Southeast Asia region. However, Chinese engagements in fueling violent extremism and conflict escalation in Myanmar is unclear and paradoxical, yet, prominent. China addresses only a narrow range of conflict issues that reinforce its interests, narrative, and position, but neglects the complex drivers of identity conflicts and the Burmese government's involvement in human rights violations (Andrienne, 2018).

For instance, China's economic interest informs its support for both the Burmese government and some strong EAOs in states like Rakhine, Kachin, and Northern Shan. It employs a political strategy that enables it to continue running its extractive economies in sub-national areas while also supporting clandestine market systems of EAOs. In regions controlled by EAOs, some ethnic armies rely on the sale of drugs, natural resources like opium and timber, and other raw materials to Chinese multi-nationals and the Chinese government to generate revenue to fund their military enterprises (Clarke et al., 2019; Bynum, 2018; ISDP, 2018). Interview 5 mentioned that "Chinese projects in EAO areas is increasing under-development of communities. These Chinese projects do not have any economic or peace benefits for the communities; ... instead, they increase division and hatred for the government because they [government] enjoy the benefits alone". Interviews 7, 11, and 18's response highlighted that larger EAOs, like United WA and others in Kachin and Shan, benefit from China because its government provides them with military training, weapons, and patronise their illicit market systems. Thus, they are well-equipped and have the resources to mobilise more youth to participate in extremism.

\section{SUMMARY OF KEY FINDINGS}

This research investigated why and how youths radicalise in Myanmar and how radical ideologies motivate their mobilisation for violent extremism. The research findings revealed the following:

i. As a politically-motivated phenomenon, radicalisation and extremism in Myanmar occur because repressive state authorities institutionalise discriminatory practices that promote structural violence against ethnic minorities. These practices discount their political concerns, which they consider important to their socio-political thriving. 
ii. The perpetuation of structural violence - direct and in direct violation of minorities through military actions and discriminatory political institutions sustain ethnonational ideologies and the maintenance of hardlines that exacerbate violent conflicts and structural liberation demands. Youths lie at the heart of amplifying these ethnonational ideologies and hardlines because of the perceived obligations that they have towards defending their ethnopolitical identity.

iii. Ethnonationalism enables the radicalisation of youth and facilitates their mobilisation for violence. These ideologies are sustained by youths who participate in EAOs by using fear and acts of terror on diverse populations to advance their socio-political change agenda. For them, violence remains a viable method for resisting structural injustices perpetrated by an "illegitimate regime", and to achieve their liberation agendas.

iv. Myanmar's national youth policy does not clarify which category of people are youths. This disparity creates a variation in how the research interlocutors described and categorised youths across the country. However, despite this ambiguity, participants' responses revealed that whichever category of people are considered youths is not a reflection of who gets targeted with radical ideologies to influence the escalation of extremely violent behaviours. Instead, personal experience and demographics play significant roles in understanding which people are mostly radicalised than others. In this case, youths in rural communities across sub-national areas engage in violent extremism more than those in big cities like Yangon and Mandalay. Some youths in EAOs are forcefully conscripted, either as a penalty for drug abuse or representation requirement for each family. Also, although older people participate in escalating sub-national conflicts, youths remain active foot-soldiers in upholding their ethnic group's political values and engage in active combat actions on their behalf.

v. Although some youths embrace violent extremism, many others engage in peacebuilding actions to enlighten their peers against indulging any forms of violence and build their capacity to adapt non-violent strategies for demanding social change. These peacebuilding efforts are facilitated through training workshops, social media actions, community-led youth initiatives like reading clubs and storytelling, sports, non-violent social movements, and transnational coalitions. The interconnectedness of different choices and actions that people adopt to promote socio-political change in Myanmar reinforces that radicalisation and engagement in violent extremism is a function of human agency.

vi. There is often manipulation of the intentions of some youths that implement social cohesion-related initiatives by the central government. Some of these initiatives include diverse social movements, usually on social media (Facebook), that demand peaceful resolution of conflicts, respect for diversity, and an adequate inclusion and representation of minorities in national political processes. Some of these youths are labelled "enemies of the state" and accused of inciting youth rebellion against the Central Government. For instance, others, like some Rohingya youths who implement education programmes for Muslim communities in Rakhine State are placed under heavy surveillance by the military and arrested at will, making them prisoners of the current political system.

vii. In Myanmar, violent extremism is primarily politically-motivated rather than being inspired by religion as many pieces of literature attempt to portray it. It springs from frustration and disillusionment, which necessitates liberation from repressive authorities. While the conflicts respond to structural injustices and disparities between majority and minority ethnicities, Buddhism is mostly weaponised and integrated into mainstream political debates to deepen resentment against an already vulnerable Muslim community. This religious depiction of extremism creates manipulation and seemingly portrays all Burmese-speaking ethnic groups in Myanmar as a homogenous community, which is an incorrect representation of the realities on the ground. Following this position, this research departs from many dominant arguments that consider religion to be a foundational driver of radicalisation and extremism in societies.

viii. China's engagement in Myanmar's peace process is complicated and unclear. While it claims to be mediating between the conflict parties and blocks mediation efforts from the United Nations and other interested parties from outside Southeast Asia, it is mostly interested in pursuing its economic and political interests in the country. China allegedly plays double-standard politics by providing military capacity - training and material resources - to the Tatmadaw and EAOs, and patronises clandestine market systems that non-state actors operate in many sub-national areas. Even though China does not directly facilitate extremism in Myanmar, its actions sustain violence by capitalising on the country's chaotic state to accomplish its economic and political goals.

ix. Although ethnonationalism is the central ideology that incites violence in Myanmar, this research acknowledges the role that other causal factors like religion, technology (i.e., social media, mainly Facebook) and hate speech play in facilitating radicalisation and deep-seated hatred among diverse identity groups, in like many other places where violent extremism occurs. This point proves that 
there is no distinct explanation for the emergence of radicalisation and violent extremism in societies. Instead, a combination of multiple structural, cultural, historical, infrastructural and technological factors could intersect to enable these phenomena across different localities.

\section{DISCUSSION}

The concept of radicalisation and extremism in societies, including Myanmar, remains a prominent debate, particularly in the face of contemporary forms of identity and ideological conflicts. However, several attempts to understand the concept remains problematic. One of such challenges is associated with 'language'. The use of the term "radicalisation and violent extremism" 'loosely' by peace and development practitioners, academics and policy actors without a generally accepted definition increases their subjectivity and constitutes a significant source of confusion. These subjective descriptions enable stereotypes against particular communities (such as Muslims), thereby creating far-reaching effects on the agency of such groups. It also opportune many governments, including weak states whose legitimacy are under question, to perpetuate hegemony and structural violence that impedes opportunities for inclusivity across a broader population. Also, it provides justifications for other inhumane forms of statesanctioned violence against specific populations, which negates the provisions and fundamental tenets of the universal declaration of human rights.

In addition, the varied definitions of extremism by policy actors enables the proscription of specific actors as 'terrorists' while calling other groups (who are also guilty of gross violations) allies or liberation fighters as with Libya during the ousting of Muammar Ghaddafi, Yoweri Museveni's National Resistance Army (NRA) during the Ugandan civil war, the Mujahedeen during the Soviet's occupation of Afghanistan, among other examples. Although it is essential to gain clarity on the concept of radicalisation and violent extremism, it is also crucial to underscore the complexity that is associated with the various factors that drive their emergence within societies. Hence, the likely oversimplification of these phenomena could dismiss their complexity. Instead, the contextualisation of the narratives and a systematic assessment of the factors that cause radicalisation and extremism to the different environments they occur would clarify the strategies required to confront the problems. Also, the description of both phenomena should not be confined to specific theoretical understanding or scrutiny; however, their real-life effects should form the empirical basis upon which theories and programmes are developed. By implication, theorising radicalisation and violent extremism should address the cognitive, psychological, physical, and structural dimensions associated with their manifestations across societies.

Within Myanmar, the drivers of extremism manifest in different forms: ethnonationalism and Buddhist nationalism.
However, the most prominent is ethnonationalism. While there appears to be a clamp-down on ethnic minorities, the adoption of regional insurgency as a strategy to advance political grievances and legitimacy remains an ongoing action. Self-determination seemingly depicts loyalty to one's ethnic group, deprived of its political recognition, leadership and control. As the conflicts escalate in the country, ethnonationalism has become complicated to understand. However, the research respondents represent it as an agenda of ethnic [structural] liberation from a repressive central state. As many youths become radicalised through ethnonational ideologies, the contextualisation of violent extremism within this society must push back on existing anti-Muslim stereotypes. Instead, addressing both the structural and attitudinal factors that enable the proliferation of politicallymotivated extremism and its manifestation is crucial.

Therefore, addressing the factors that drive extremism in Myanmar requires addressing the challenges associated with weak state institutions, endemic distrust of the central government, respect for human rights, and the strengthening of opportunities that support inclusivity in security, economic and political decision-making, governance, and the rule of law. Although there is a National Ceasefire Agreement (NCA), the exclusion of some EAOs because they refuse to transform into Border Guard Forces (BFFs), and the fragmentation of some larger EAOs still impedes the road to peace in Myanmar. While fragmentation of extremist groups could serve as leverage for peace negotiation, the legitimacy of break-out groups and the influence that they could have in sustaining negotiated outcomes remains challenging, especially when they hold "undefined" or "unaccepted" identities and statuses within the localities that they control. The way out of such a dilemma is to promote more inclusive processes towards peace- and institution-building. When negotiations collapse, it becomes difficult to discern a concrete strategy for moving societies away from conflicts towards more constructive reforms or transformative agendas. Hence, dealing with the structural factors that increase political exclusion, under-development, and sectional governance can prevent radicalisation and extremism. These efforts will reduce the vulnerability of minorities and their recruitment into extremist organisations.

Similarly, beyond promoting inclusive political voices as a preventative strategy, conflict parties, especially governments, should comprehensively implement the outcomes of political settlements without reneging on agreed commitments. Evidence, such as in the Columbia and South Sudan peace process, reveal that when actors renege on political commitments in post-conflict reconstruction, the resumption of violence is inevitable. Similarly, the adoption of consistent and strategic dialogues reduces the risk of an increase or recurrence of violent conflicts. The use of hard-power to tackle extremism, especially when they emerge due to structural injustices and discriminatory practices, increases the legitimacy and popularity of alleged hardliners and stirs some 
level of public support for their actions, particularly among members of their immediate constituencies with whom their actions resonate.

Meanwhile, although many political and academic arguments synonymise violent extremism as terrorism, it is critical to distinguish between the different ambitions of extremist groups and the forms of extremism that become terrorism. While there may be interplay of factors between different forms of extremism that result in global terrorism, scholars and practitioners should identify the nuanced factors that enable diverse forms of extremism across societies. This research asserts that because many positions associate terrorism with Islamist Jihad (a misrepresentation of Islam's tenets), it becomes imperative to understand that the manipulation or politicisation of religion make it challenging to clarify the varying motivations for radicalisation and violent extremism, particularly when they are masked with a religious undertone. Therefore, unpacking the various factors, including systemic drivers, that escalate extremism will prevent the stereotype of some religious communities as extremists, and challenge the use of state-sanctioned violence by repressive states. Besides, when political extremism is consistently validated as a liberation struggle, especially by peace and development practitioners, we may be failing to acknowledge the ethics associated with corroborating such positions as legitimising any form of direct violence. Thus, engaging a case-by-case assessment of violent extremism provides a useful lens for understanding ' $w h y$ and how' people radicalise or mobilise rebellion against 'legitimate' authorities.

\section{IMPLICATIONS AND RECOMMENDATIONS OF THE RESEARCH}

Since this research considered ethnonationalism as a fundamental driver of radicalisation and political extremism in Myanmar, it presents some implications and recommendations that will be useful for future peacebuilding action-research, policymaking (such as foreign policy and humanitarian/donor decision-making), and programme design that relate to preventing and countering violent extremism.

i. Throughout the country, there is a significant variation in the effectiveness and legitimacy of political power brokers, which creates significant impacts on conflict dynamics. This variation influences the commitment of the different political power-brokers to their different constituencies and the negotiated settlements because of the considerations given to incentives available to them to protract violence or support peace. Hence, policy responses to extremism in Myanmar should carefully examine sub-national fragility, and the different political and economic incentives necessary to facilitate positive political changes.

ii. The use of military force, such as clearance operations, in sub-national areas to respond to political grievances stiffens resentment and amplifies ideologies like ethnonationalism. These 'hard-power' strategies increase youths' recruitment into ethnic armies and protract generational hatred and divide across diverse ethnic groups. It also prevents public and political institutions' accountability to the citizens, which they are required to serve.

iii. As the country transitions towards a "complete democracy", institutional reforms are critical to transforming structural violence perpetrated against ethnic minorities. These reforms should be institutionalised and operationalised through collaborative frameworks that acknowledge the intersection of different political and social needs of ethnic groups. Diverse political and humanitarian efforts should also seek to address the trauma associated with the over seven decades of civil war to prevent political extremism's proliferation across sub-national populations.

iv. Although there is a National Ceasefire Agreement (NCA) in place, the inclusion of diverse ethnic actors towards deciding its provisions and implementation is highly selective. The imposition of the NCA on local populations delegitimises the negotiations, presenting it as elites' decisions that ignore the lived realities of some marginalised communities. It also reverberates power asymmetry between various ethnic groups, thereby sustaining tendencies for the recreation of political cycles of violence and protracted suffering. Also, the poor representation of specific demographics like the youth and women in the NCA ignores their roles in violence and peacebuilding, sustains cultural patriarchy and classism, and neglects the relevance of social groups in the sustainability of peace agreements. Therefore, it becomes imperative for the central government (including the Tatmadaw) to broaden the representation and participation of different actors across the country in diverse peacebuilding efforts at various levels.

v. The non-recognition of specific communities, particularly the Rohingya, as citizens, because of complicated citizenship laws, encourage discrimination. This type of attitude is shaped by some dominant policy framings that attempt to label Muslims as terrorists and empowers state-sanctioned terrorism against this religious community. The recognition of diversity would encourage respect, mutualism, and collaboration towards addressing social problems. As part of the country's transition towards democracy, it is vital to revisit discriminatory citizenship laws, especially through consultations with various groups. These consultations should encourage groups to make compromises that will favour social cohesion and peaceful co-existence. 
vi. More broadly, the influx of global aid and investments into Myanmar to support the burgeoning economy are paradoxical. While it encourages foreign direct investment and improved societal welfare, the absence of institutional and political reforms increases the likelihood that these resources would benefit one ethnic group more than others. Glaring inequality will sustain frustration, which then impacts the achievement of collective human flourishing and strategic peacebuilding. Besides, the plausibility that these investments will contribute to and sustain state terrorism and ethnic insurgency is high. Therefore, countries and humanitarian aid agencies that provide foreign assistance to Myanmar must improve their aid guidelines to be more stringent to ensure that their resources are utilised to ameliorate people's living conditions and are not diverted to sustain repression and violence. These parameters should be operationalised through and monitored by the consulates and embassies of these countries, which are domiciled in Myanmar.

\section{CONCLUSION}

The proliferation of radicalisation and extremism in Myanmar proves quite complex to articulate. Feelings of relative deprivation and frustration that are fuelled by historical grievances over unmet political demands and exploitations sustain the complexity of ethnonationalism and how it constitutes a radical ideology for escalating violent extremism. Also, manipulating the conventional prescription of Islam as an enabler of terrorism by the Central Government blurs citizens' ability to recognise ongoing conflicts in the country as politically motivated extremism. The consecutive contests for political legitimacy, territorial and resource control, or liberation from the political hegemony of the Central Government impedes opportunities to improve livelihoods, ensure de-radicalisation, and achieve just peace. Therefore, conflict escalation in Myanmar challenges the cosmic description of violent extremism and radicalisation in modern scholarly and policy debates, which a systemic assessment of socio-political structures will reveal. This research emphasises that implementing institutional reforms within Myanmar and ensuring comprehensive processes of inclusivity for all groups will eliminate the superiority of one ethnic group over another, and reduce systemic deprivation. By considering the history of Myanmar's conflicts, a genuine transformation of the central government's behaviour towards ethnic minorities may soften political hardlines and the ideologies that radicalise youths and mobilise their engagements in extreme violence in defence of their ethnopolitical identity. Therefore, compromises by state and non-state actors, devolution or appropriation of power to different ethnic leaderships in sub-national areas, and understanding the unique roles of youths in political extremism and peacebuilding play crucial roles in preventing the amplification of structural liberation ideologies. Instead, these actions will guide the political and social cohesion programmes designed to address the various conflicts and political needs of several ethnopolitical groups in the country.

\section{REFERENCES}

[1] Ackermann, A. (2003). The Idea and Practice of Conflict Prevention. Journal of Peace Research, 40(3), 339-347.

[2] Al-Lamim, M. (2009). Studies in Radicalisation: State of the Field Report. Politics and International Relations Working Paper. Retrieved from: https://static1.squarespace.com/static/566d81c8d82d5ed309b2e93 5/t/567ab488b204d58613bf92aa/1450882184032/Studies_of_Radi calisation_State_of_the_F.pdf

[3] Andrienne, J. (2018). Understanding China's Response to the Rakhine Crisis. United States Institute of Peace. Retrieved from: https://www.usip.org/sites/default/files/2018-02/sr419understanding-chinas-response-to-the-rakhine-crisis.pdf

[4] Ban, K. (2015). Plan of Action to Prevent Violent Extremism: United Nations Global Counter-Terrorism Strategy. Retrieved from:

https://www.un.org/en/ga/search/view_doc.asp?symbol=A/70/675

[5] Borum, R. (2012). Radicalisation into Violent Extremism II: A Review of Conceptual Models and Empirical Research. Journal of $\begin{array}{llll}\text { Strategic } & \text { Security, 4(4), 37-62. DOI: }\end{array}$ http://dx.doi.org/10.5038/1944-0472.4.4.2.

[6] Bowen, J. (2017). Why Preventing Violent Extremism Needs Sustaining Peace. International Peace Institute. Retrieved from: https://www.ipinst.org/2017/10/why-preventing-violentextremism-needs-sustaining-peace

[7] Boyd-MacMillan, E. (2019). A Mental Health Approach to Understanding Violent Extremism. Ex Post Paper RAN Policy \& Practice. Retrieved from: https://ec.europa.eu/homeaffairs/sites/homeaffairs/files/what-we-

do/networks/radicalisation_awareness_network/about-ran/ran-hand-sc/docs/ran_hsc_prac_mental_health_03062019_en.pdf

[8] Breuer, J. \& Elson, M (2017). Frustration - Aggression Theory. In Sturmey, $\mathrm{P}$ (Ed.). The Wiley Handbook of Violence and Aggression, p. 1-12. United Kingdom: John Wiley \& Sons Ltd. DOI: 10.1002/9781119057574.whbva040.

[9] Buchanan, J. (2016). Militias in Myanmar. Yangon: The Asia Foundation. Retrieved from: https://asiafoundation.org/wpcontent/uploads/2016/07/Militias-in-Myanmar.pdf

[10] Burke, A., Williams, N., Barron, P., Jolliffe, K. \& Carr. T. (2017). The Contested Areas of Myanmar: Subnational Conflict, Aid, and Development. Yangon: The Asia Foundation. Retrieved from: https://asiafoundation.org/publication/contested-areas-myanmarsubnational-conflict-aid-development/

[11] Bynum, E. (2018). Understanding Inter-Ethnic Conflict in Myanmar. Retrieved from: https://www.alnap.org/system/files/content/resource/files/main/acl eddata.com-Understanding\%20Inter-

Ethnic\%20Conflict\%20in\%20Myanmar.pdf

[12] Callahan, M.P. (2007). Political Authority in Burma's Ethnic Minority States: Devolution, Occupation and Coexistence. Washington DC: East-West Center Policy Studies, No. 31.

[13] Chalk, P. (2013). On the Path of Change: Political, Economic and Social Challenges for Myanmar. Australian Strategic Policy Institute (ASPI). Retrieved from: https://www.files.ethz.ch/isn/175091/On\%20the\%20path\%20of\%2 0change_\%20political,\%20economic\%20and $\% 20$ social\%20challe nges $\% 20$ for\%20Myanmar.pdf

[14] Clarke, S.L., Myint, S.A.S., \& Siwa, Z.Y. (2019). Re-examining Ethnic Identity in Myanmar. Retrieved from: https://reliefweb.int/report/myanmar/re-examining-ethnic-identitymyanmar

[15] Cortright, D., Seyle, C., \& Wall, K. (2017). Governance for Peace: How Inclusive, Participatory and Accountable Institutions 
Promote Peace and Prosperity. USA: Cambridge University Press.

[16] Cuesta, B.L. (2016). Myanmar: The Roadmap 7 Steps to a Disciplines Democracy. Spanish Institute for Strategic Studies. Retrieved from: http://www.ieee.es/en/publicacionesnew/documentos-de-opinion/2016/DIEEEO91-2016.html

[17] Davis, Q. (2016). Building Infrastructure for Peace: The Role of Liaison Offices in Myanmar's Peace Process. Centre for Peace and Security Studies. Retrieved from: http://www.centrepeaceconflictstudies.org/wpcontent/uploads/Role-of-Liaison-Offices-Update-jan.15.pdf

[18] Davis, Q., Hyma, R., Kirkham, A., Kry, S., Martin, M., Ngarm, S.P., Simbulan, K., Shahpur, T., Visser, L. (2016). We Want Genuine Peace: Voices of Communities from Myanmar's Ceasefire Area 2015. The Centre for Peace and Conflict Studies (CPCS). Also available on: http://www.centrepeaceconflictstudies.org/wpcontent/uploads/We-Want-Genuine-Peace-FINAL-ENG-WEB.pdf

[19] Egreteau, R. \& Mangan, C. (2018). State Fragility in Myanmar: Fostering Development in the Face of Protracted Conflict. LSEOxford Commission on State Fragility, Growth and Development. Retrieved from: https://www.theigc.org/wpcontent/uploads/2018/08/Myanmar-Report-final.pdf

[20] Emah, E.B. (2020). The Politics of Inclusion in Myanmar's Nationwide Ceasefire Agreement. E-International Relations. July 28, 2020. Retrieved on: https://www.e-ir.info/2020/07/28/opinionthe-politics-of-inclusion-in-myanmars-nationwide-ceasefireagreement/

[21] Galtung, J. (1969). Violence, Peace, and Peace Research. Journal of Peace Research, 6(3), 167-191.

[22] Gravers, M (1999). Nationalism as Political Paranoia in Burma: An Essay on the Historical Practice of Power. London: Routledge.

[23] Glazzard, A. (2017). Losing the Plot: Narrative, Counter-Narrative and Violent Extremism. International Centre for CounterTerrorism. DOI: 10.19165/2017.1.08.

[24] Hardy, K. (2018). Comparing Theories of Radicalisation with Countering Violent Extremism Policy. Journal for Deradicalisation, 15, 76-110.

[25] Hendrickson, D. \& Karkoszka, A. (2002). The Challenges of Security Sector Reform. SIPRI Yearbook. Retrieved from: https://www.sipri.org/yearbook/2002/04

[26] International Crisis Group (2014). Myanmar: The Politics of Rakhine State. Crisis Group Asia Report. Retrieved from: https://www.crisisgroup.org/asia/south-eastasia/myanmar/myanmar-politics-rakhine-state

[27] International for Security and Development Policy (2018). A Return to War: Militarized Violence in Northern Shan. Asia Paper. Retrieved from: http://isdp.eu/content/uploads/2018/05/AReturn-to-War-Print-V-w-cover-21.05.18.pdf

[28] Jaquet, C. (2014). The Kachin Conflict: The Search for Common Narratives. International Management Group.

[29] Jasko, K., Webber, D., Kruglanski, A.W., Gelfand, M., Taufiqurrohman, M., Hettiarachchi, M., \& Gunaratna, R. (2019). Social Context Moderates the Effects of Quest for Significance on Violent Extremism. Journal of Personality and Social Psychology, 1-23. http://dx.doi.org/10.1037/pspi0000198

[30] Jolliffe, K (2014). Ethnic Conflict and Social Services in Myanmar's Contested Regions. Yangon: The Asia Foundation. Retrieved from: https://asiafoundation.org/resources/pdfs/MMEthnicConflictandSo cialServices.pdf

[31] Jolliffe, K. (2015). Ethnic Armed Conflict and Territorial Administration in Myanmar. Yangon: The Asia Foundation. Retrieved from: https://asiafoundation.org/resources/pdfs/ConflictTerritorialAdmin istrationfullreportENG.pdf

[32] Kruglanski, A., Jasko, K., Webber, D., Chernikova, M., \& Molinario, E. (2018). The Making of Extremists. Review of General Psychology, 22(1), 107-120.

[33] Kyaw, N.N. (2016). Islamophobia in Buddhist Myanmar: The 969 Movement and Anti-Muslim Violence. In Crouch, M (ed.). Islam and the State in Myanmar: Muslim-Buddhist Relations and the Politics of Belonging, 183-210. India: Oxford University Press.

[34] Lakhani, S. (2012). Preventing Violent Extremism: Perceptions of Policy from Grassroots and Communities. Howard Journal, 51(2), 190-206.

[35] Lake, D. A. (2002). Rational Extremism: Understanding Terrorism in the Twenty-first Century. Dialogue-IO, 15-29.

[36] Luengo-Cabrera, J. \& Pauwels, A. (2016). Countering violent extremism: The Horn of Africa. Brief Issue. Retrieved from: https://www.researchgate.net/publication/315689481_Countering_ violent_extremism_the_Horn_of_Africa

[37] Liden, K. (2018). A War on Values? On the Politics of Countering the Values of Violent Extremism. Society, Security, and Technology, 1(1), 18-37.

[38] Mandaville, P. \& Nozell, M. (2017). Engaging Religion and Religious Actors in Countering Violent Extremism. United States Institute of Peace Special Report. Retrieved from: https://www.usip.org/sites/default/files/SR413-Engaging-Religionand-Religious-Actors-in-Countering-Violent-Extremism.pdf

[39] Maskaliunaite, A. (2015). Exploring the Theories of Radicalisation. International Studies, 17(1), 9-26.

[40] Mroz, J. (2009). Lone Wolf Attacks and the Difference Between Violent Extremism and Terrorism. Retrieved from: http://www.ewi.info/lone-wolf-attacks-anddifference-betweenviolent-extremism-and-terrorism

[41] Mušić, S. (2016). The Role of Education in Preventing Violent Extremism and Radicalism. Retrieved: from: https://www.researchgate.net/publication/324942495_The_Role_o f_Education_in_Preventing_Violent_Extremism_and_Radicalism

[42] Mušić, S. (2018). Religious Aspects of the Phenomenon of Violent Extremism. Retrieved from: https://www.researchgate.net/publication/324992185_Religious_a spects_of_the_phenomenon_of_violent_extremism

[43] Nasser-Eddine, M., Garnham, B., Agostino, K. \& Caluya, G. (2011). Countering Violent Extremism (CVE) Literature Review. Australia: Counter-Terrorism and Security Technology Centre, DSTO Defence Science and Technology Organisation.

[44] Paung Sie Facility (2017). Youth \& Everyday Peace in Myanmar: Fostering the Untapped Potential of Myanmar's Youth. Retrieved from:

https://www.jointpeacefund.org/sites/jointpeacefund.org/files/docu ments/youth_paper_english.pdf

[45] Renshaw, C.S. (2013), Democratic Transformation and Regional Institutions: The Case of Myanmar and ASEAN. Journal of Current Southeast Asian Affairs, 32 (1), 29-54.

[46] Ricigliano, R. (2012). Making Peace Last. A Tool Box for Sustainable Peacebuilding. Boulder, London: Paradigm Publishers.

[47] Sageman, M. 2017. Turning to Political Violence: The Emergence of Terrorism. Philadelphia: University of Pennsylvania Press.

[48] Schirch, L. (2018). The Landscape of Terror. In Schirch, L. (ed.). The Ecology of Violent Extremism, p. 5-20. Maryland: Rowman \& Littlefield Publishing Group, Inc.

[49] Smith, A. (2018). Myanmar-Watching: Problems and Perspectives. Griffith Asia Institute. Retrieved from: https://www.griffith.edu.au/_data/assets/pdf_file/0034/272959/Re gional-Outlook-Paper-58-Selth-web.pdf

[50] Shauri. H.S \& Wanjala, S.W. (2017). Radicalization and Violent Extremism at the Coast of Kenya: "Powerful Voices of Coexistence, Are They Being Heard?" In Njogu, K. \& Cage, I. (eds.). Meeting of Cultures at the Kenyan Coast, p. 145-154. Kenya: Twaweza Communications Ltd.

[51] Simbulan, K. (2018). When Perceptions Define Reality: Implications and Challenges after the August 2017 Crisis in Rakhine State. Myanmar: RAFT.

[52] South, A. (2009). Ethnic Politics in Burma: States of Conflict. New York, USA: Routledge.

[53] Staniland, P. (2012b). States, Insurgents, and Wartime Political Orders. Perspectives on Politics, 10 (2), 43-64.

[54] Stephens, W., Sieckelinck, S. \& Boutellier, H. (2019a). Preventing Violent Extremism: A Review of the Literature. Studies in Conflict 
\& Terrorism, 1-16. https://doi.org/10.1080/1057610X.2018.1543144.

[55] Stephens, W. \& Sieckelinck, S. (2019b): Being Resilient to Radicalisation in PVE Policy: A Critical Examination. Critical Studies on Terrorism, 1-24. DOI: 10.1080/17539153.2019.1658415.

[56] Stokke, K., Vakulchuk, R., Øverland, I. (2018). Myanmar: A Political Economy Analysis. Norwegian Institute of International Affairs. Retrieved from: https://reliefweb.int/sites/reliefweb.int/files/resources/Myanmar__A_Political_Economy_Analysis_-

_Norwegian_Institute_of_International_Affairs_2018.pdf

[57] Taylor, R. H. (2005). Do States Make Nations? The Politics of Identity in Myanmar Revisited. South-East Asia Research, 13(3), 261-286.

[58] The Belmont Report (1979). Retrieved from: http://www.hhs.gov/ohrp/humansubjects/guidance/belmont.html

[59] Tun, T.Z \& Soe, H.M. (2020). Thousands of Myanmar Workers Rally for Higher Minimum Wage. Myanmar Times. Retrieved from: https://www.mmtimes.com/news/thousands-myanmarworkers-rally-higher-minimum-wage.html

[60] United Nations Development Programme (2016). UNDP Global Meeting on Preventing Violent Extremism and Promoting Inclusive Development, Tolerance, and Diversity. Retrieved from:
https://www.undp.org/content/dam/norway/img/Concept\%20note PVE-no\%20agenda.pdf

[61] United Nations Security Council Resolution 2250. Retrieved from: https://www.un.org/press/en/2015/sc12149.doc.htm

[62] Weinberg, L. \& Pedahzur, A. (2004). Religious Fundamentalism and Political Extremism. Nova Religio 8(2), 106-109.

[63] Wells, T. (2016). Making Sense of Reactions to Communal Violence in Myanmar. In Cheesman, N \& Farrelly, N. (eds.). Conflict in Myanmar: War, Politics, Religion, p.245-260. Singapore: Yusof Ishak Institute.

[64] Williams, M.C. (2015). Myanmar's Troubled Path to Reform Political Prospects in a Landmark Election Year. Chatham House: The Royal Institute of Political Affairs. Retrieved from: https://www.chathamhouse.org/sites/default/files/field/field_docu ment/20150226Myanmar.pdf

[65] Zillmann, D., \& Cantor, J. R. (1976). Effect of Timing of Information about Mitigating Circumstances on Emotional Responses to Provocation and Retaliatory Behavior. Journal of Experimental Social Psychology, 12(1), 38-55. DOI:10.1016/0022-1031(76)90085-8.

[66] Myanmar at a Glance. Retrieved from: https://asiafoundation.org/wp-content/uploads/2017/10/MyanmarTStateofConflictandViolence.pdf 